\title{
Production and evaluation of albino mutants of Sporothrix schenckii*
}

\author{
Produção e avaliação de mutantes albinos de Sporothrix schenckii \\ Márcia de Oliveira Nobre ${ }^{1}$, Tatiana de Ávila Antunes², \\ Mário Carlos Araújo Meireles ${ }^{2} \&$ Laerte Ferreiro $^{3}$
}

\begin{abstract}
Melanin is an important factor intrinsically related to the virulence of the Sporothrix schenckii. Mutant albino conidia are usually used as inoculants for the evaluation of the properties of melanin in experimental models for the study of sporotrichosis. The goals of this study were to analyze the presence of melanin in S. schenckii conidia, and to produce and evaluate mutant albino forms of S. Schenckii conidia. Four distinct isolates were cultured in PDA, supplemented or not with triciclazole, and in YEPD. A portion of the samples was exposed to $300 \mathrm{ergs} / \mathrm{mm}^{2}$ of UV radiation to generate mutants albino forms. Following the incubation, cultures were analyzed, CFU were determined, and fragments were removed for the ultrastructural analysis, to be cultured once more in YEPD e BHI. Albino colonies were exposed to visible light; all $S$. schenckii isolates produced melanin, and survival and viability were $66 \%$ and $96 \%$ for albino conidia. Melanin granules were visible in the cell wall of pigmented conidia, but not in albino conidia. All conidia reverted to both the pigmented and the yeast forms, and albino colonies photoreactivated. All isolates analyzed in this study generated DHN melanin. Moreover, despite the exposure to UV radiation $\left(300 \mathrm{ergs} / \mathrm{mm}^{2}\right)$ being lethal to a significant portion of the colonies, the viability and conversions to the pigmented and yeast forms in surviving colonies did not appear to be affected. Also, albino colonies photoreactivated upon exposure to visible light.
\end{abstract}

Key words: Sporothrix schenckii, albino mutants, UV light, survival, viability.

\section{RESUMO}

A melanina é considerada como importante fator na virulência do Sporothrix schenckii. Para avaliar as propriedades da melanina os conídios mutantes albinos são utilizados como inóculo. Os objetivos deste trabalho foram analisar a presença de melanina nos conídios de $S$. schenckii, produzir e avaliar mutantes albinos de S. schenckii. Foram utilizados quatro isolados, cultivados em PDA com e sem triciclazol e também em YEPD. Parte das placas foram expostas 300ergs de radiaçãoUV $/ \mathrm{mm}^{2}$ para obter os conídios mutantes albinos. Após a incubação os cultivos foram analisados, contadas as UFCs e fragmentos foram removidos para estudo da ultraestrutura e novamente cultivados em YEPD e BHI. As colônias albinas foram expostas à luz. Todos os isolados de S. schenckii produziram melanina, os conídios albinos apresentaram $66 \%$ de sobrevivência e $96 \%$ de viabilidade. Nos conídios pigmentados foram observados grânulos de melanina na parede celular, e nos albinos, ausência destes grânulos. Todos retornaram a morfologia pigmentada e converteram a forma leveduriforme e as colônias albinas fotorrepararam. Os resultados demonstram que todos os isolados estudados produzem melanina DHN, e a exposição dos conídios pigmentados a 300ergs de radiação $\mathrm{UV} / \mathrm{mm}^{2}$, causa morte, mas não altera a viabilidade e a conversão para forma pigmentada e leveduriforme daqueles que sobreviveram, e as colônias albinas fotorreparam após exposição à luz.

Descritores: Sporothrix schenckii, mutantes albinos, sobrevivência, viabilidade.

*This manuscript is based on a Dissertation submitted as partial fulfillment of the requirements for the degree of Doctor of Veterinary Sciences of the Programa de Pós-graduação em Ciências Veterinárias (PPGCV), Faculdade de Veterinária (FAVET) de Porto Alegre, Universidade Federal do Rio Grande do Sul (UFRGS), Porto Alegre, Brazil. 


\section{INTRODUCTION}

Microorganisms, plants, and animals, produce melanins, which increases chances of survival in the environment, and are often considered an important factor associated with the virulence of fungal organisms. Melanins are dark or dark-brown pigments only soluble in warm/hot alkaline solutions, resistant to cold/hot acid degradation, and can be lysed by oxidant agents. Thus far, the best-described fungal melanin is DHN (1,8-dihydroxynaphthalene) melanin, also known as pentaketide melanin due to its origin from acetate through the pentaketide metabolic pathway $[1,2]$.

Following melanin synthesis inhibition or stimulation using tricyclazole in wild strains or scytalone in albino strains, respectively, DHN melanin has been demonstrated to be present in the cell wall of Sporothrix schenckii conidia [5]. Recently, this pigment was also shown to be present in the yeast form, for colonies displaying reddish-brown pigmentation [4].

The production of mutant albino colonies of Sporothrix schenckii was first described by Torres Guerrero \& Arenas-López [7], with the evaluation of the UV radiation effects on the colony morphology.

The aims of this study were (a) to analyze the presence of melanin in S. schenckii conidia; (b) to produce mutant albino forms of $S$. Schenckii conidia; (c) to evaluate these mutants in terms of survival, viability, and conversion to the pigmented and yeast forms; and (c) to verify the occurrence of photoreactivation of mutant albino colonies.

\section{MATERIALS AND METHODS}

Isolates of feline ( $\mathrm{A}$ and $\mathrm{B})$ and human $(\mathrm{C}$ and D) cases of sporotrichosis were standardized according to the McFarland's scale (tube 4) and stored frozen at $-70^{\circ} \mathrm{C}$. The presence of DHN melanin in the cell wall of conidia obtained from the isolates was verified by the inhibition of the pigment's synthesis by using 16 $\mu \mathrm{g} / \mathrm{ml}$ tricyclazole (Dow Agrosciences) 1 in potato dextrose agar® (PDA)2.

The initial dilution of tricyclazole was done with ethanol, which did not exceed $0.6 \%(\mathrm{v} / \mathrm{v})$ in the final medium, as described elsewhere [5]. All cultures for each isolate were done in triplicates. A standard solution ( $1 \mathrm{~mL}$ ) containing $S$. schenckii was added to $18 \mathrm{~mL}$ of melted and cooled PDA $\left(<50^{\circ} \mathrm{C}\right)$, to be homogenized and laid in Petri dishes. Following medium solidification, dishes were incubated at $28^{\circ} \mathrm{C}$ for seven days. Isolates were also cultured in PDA-ethanol, without tricyclazole, for the evaluation of any detrimental effect of ethanol on the fungal melanin production.

For the preparation of mutant albino forms, aliquots of $0.1 \mathrm{~mL}$ were taken from each suspension containing wild type isolates (A, B, C, and D), seeded in Petri dishes containing YEPD (triplicate), immediately exposed to $300 \mathrm{ergs} / \mathrm{mm}^{2}$ of UV radiation at $254 \mathrm{~nm}$, and incubated at $28^{\circ} \mathrm{C}$ for seven days. All manipulations and incubations were performed in the dark to prevent photoreactivation. Pigmented conidia (controls) were cultured under similar conditions as done for the albino forms, but with no exposure to UV radiation.

The ultrastructural study was performed with small fragments obtained from albino and pigmented culture forms of $S$. schenckii, upon fixation in $2 \%$ glutaraldehyde in sodium cacodylate buffer, and serial dehydration in increasing ethanol gradients, to be embedded in Epon. Thin histological slices were stained with methylene blue. Ultra thin slices were done in specific areas of each block, which were counterstained with uranyl acetate and lead citrate, and analyzed by transmission electron microscopy (TEM).

The cell survival following conidia exposure to $300 \mathrm{ergs} / \mathrm{mm}^{2}$ of UV radiation was estimated by the use of serial dilutions of the standard solution or its incubation in YEPD in Petri dishes, as described previously. After seven days of incubation, the CFU from pigmented isolates and the mutant albino counterparts were counted, compared and morphologically examined. To compare traits between counterpart pigmented and albino isolates, the average $\mathrm{CFU}$ obtained in each pigmented isolate was regarded as $100 \%$.

The conversion of mutant albino conidia to the pigmented form and the evaluation of cell viability were observed following the culture of both albino and pigmented conidia removed from $1 \mathrm{~cm}^{2}$ agar plates containing the 10-2 serial dilution of the respective fungal cultures. 
Fungal structures were scraped from the agar plates with the aid of a scalpel blade, washed in 20 $\mathrm{ml}$ PBS, homogenized, filtered, further diluted to 10 5 , to be finally cultured in YEPD, in triplicates. After seven days of incubation, CFU were counted and compared. To evaluate the conversion to the yeast form, mutant albino conidia aliquots of $1 \mathrm{ml}$, as described previously for cultures in Brain-heart broth ${ }^{\circledR}$ (BHI)3, were incubated at $37^{\circ} \mathrm{C}$ in a shaker for seven days.

The photoreactivation capacity was evaluated after the exposure of plates containing albino colonies diluted to 10-2 to visible light for 60 minutes a day, on a daily basis, for a period of 30 days.

\section{RESULTS}

All pigmented isolates of Sporothrix schenckii cultured in PDA-Ethanol displayed pigmented colonies varying from dark gray to black, whereas the isolates cultured in PDA-Ethanol-Tricyclazole turned orange in color ( Figure 1).

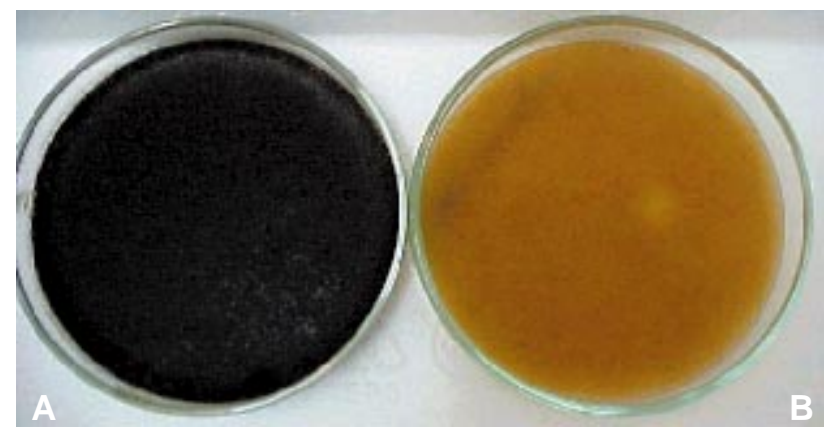

Figure 1. Sporothrix schenckii isolates after seven days of incubation. (A) Dark-pigmented colonies cultured in PDAethanol. (B) Orange-pigmented colonies cultured in PDAethanol- tricyclazole.

Isolates cultured in YEPD, not exposed to UV light, formed pigmented colonies with colorations that gradually evolved from light dark to dark gray. Wild type isolates of Sporothrix schenckii exposed to UV radiation and protected from visible light formed mutant albino colonies, i.e., colonies of white coloration, characterized by well-defined edges, compact formation, and slightly velvety in their centers and adherents to the agar (Figure 2); one isolate specimen formed colonies with irregular edges, compacted, membranous and highly adherent to the agar.

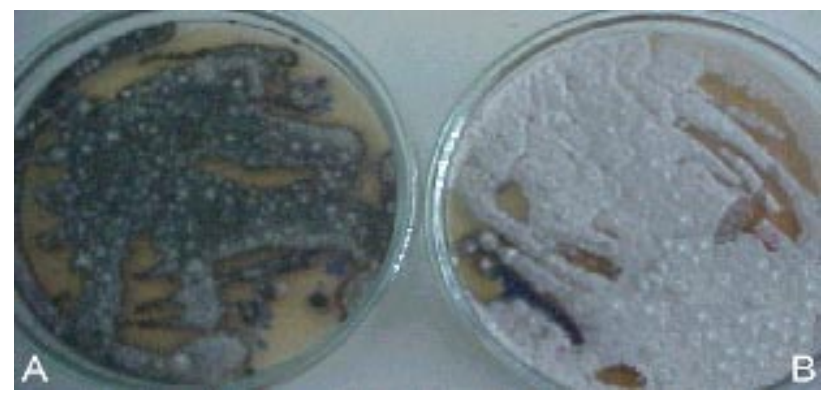

Figure 2. Sporothrix schenckii isolates after exposure to $300 \mathrm{ergs} / \mathrm{mm}^{2} \mathrm{UV}$ radiation and seven days of incubation, protected from visible light. (A) Pigmented isolates. (B) Mutant albino isolates.

Microscopically, irregular hyphae were abundant, with little branching, and rounded structures similar to conidia localized in the hyphae. Pigmented conidia of S. schenckii displayed granules of melanin surrounding the cell wall, whereas no such granules were visible in mutant albino conidia.

No estudo ultraestrutural a presença de grânulos de melanina na superfície da parede celular dos conídios selvagens e a ausência destes nos conídios albinos (figure 3), foi demonstrado o efeito mutagênico da radiação UV com a produção dos conídios albinos.
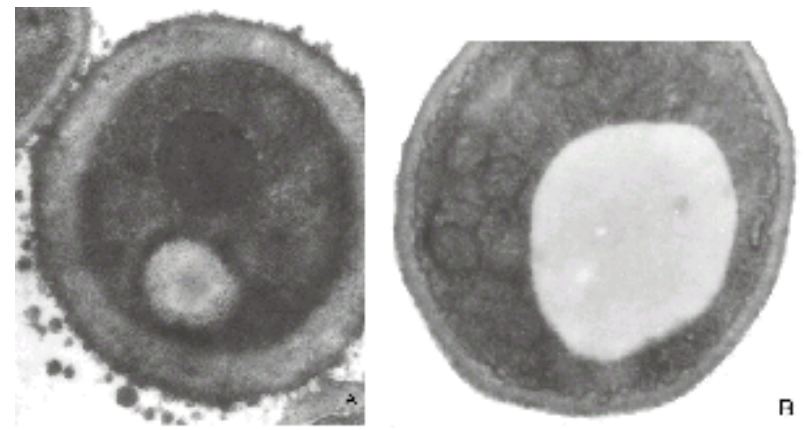

Figure 3. Transmission electro microscopy of Sporothrix schenckii, displaying the presence (A) or absence (B) of an electrodense layer in the external cell wall composed of melanin granules (A) Wild type conidia, (B) Mutant albino conidia [34,000 X magnification].

The survival of mutant albino conidia was variable, being $79 \%, 60 \%, 59 \%$, and $65 \%$ in isolates $\mathrm{A}, \mathrm{B}, \mathrm{C}$, and $\mathrm{D}$, respectively, averaging $66 \%$ when compared with the wild types. All cultured albino conidia developed pigmentation, which were morphologically similar to the pigmented cultures (Figure 4); moreover, microscopically, the mutant albino forms also reverted to the original morphology, although fragments of irregular hyphae and conidia present in the tip of the roundest condiophores were still visible. 


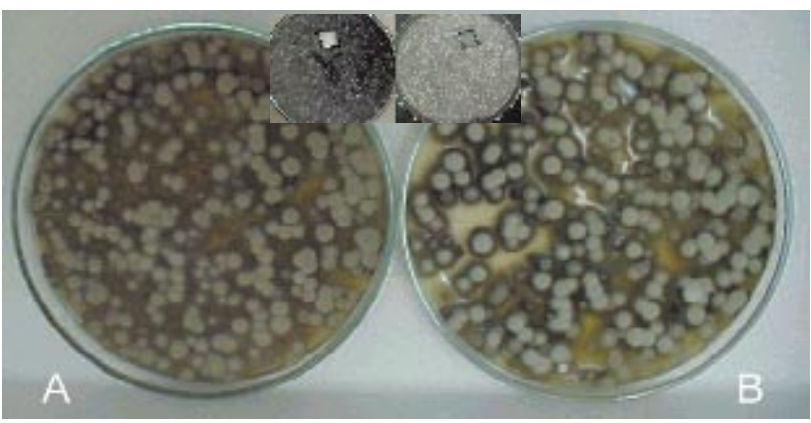

Figure 4. Sporothrix schenckii cultures in YEPD originated from wild type (A) and mutant albino conidia (B) with similar morphology and CFU that survived to $300 \mathrm{ergs} / \mathrm{mm}^{2} \mathrm{UV}$ radiation. The primary cultures from where $1 \mathrm{~cm}^{2}$ blocks of agar were used to isolate mutant and albino conidia are shown in the insets on the top.

The viability observed in mutants albino conidia from isolates $\mathrm{A}, \mathrm{B}$, and $\mathrm{D}$, and from isolate $\mathrm{C}$ were $97 \%$ and $93 \%$, respectively, averaging $96 \%$ when compared with the wild type forms.

Mutant conidia obtained from isolates A, B, C and $\mathrm{D}$ exposed to $\mathrm{UV}$ radiation reverted to the yeast form in BHI photoreactivated following the exposure to visible light for a period of 30 days, acquiring a brown coloration over time.

\section{DISCUSSION}

Romero-Martinez et al. [5] demonstrated the synthetic capacity of DHN melanin by the $S$. schenckii conidia, also showing the increase in the in vitro susceptibility of albino conidia to oxidants and to phagocytosis.

All isolates of $S$. schenckii analyzed in this study included cell wall DHN melanin-producing conidia, which was confirmed by the appearance of orange-like cultures in media containing tricyclazole and ethanol [5]. Tricyclazole halts melanin biosynthesis by inhibiting two specific reductases, which prevent the transformation of $1,3,6,8$-THN to scytalone and $1,3,8$-THN to vermelone, causing an accumulation of the melanin intermediates flaviolin and $2 \mathrm{HJ}(2-$ hidroxyjuglone) $[1,2]$.

The ability of tricyclazole to inhibit melanin biosynthesis was first observed in Verticillium dahliae [6]. For the tricyclazole concentrations utilized in that study, no flaviolin accumulation was detected in the medium, with only small amounts of $2 \mathrm{HJ}$ being observed; possibly, high concentrations of tricyclazole are required to inhibit the reduction of $1,3,6,8-\mathrm{THN}$ to scytalone [5].
In this study, macro e micromorphological changes were observed to be caused by the UV radiation, which had been demonstrated to occur with radiation doses of 300 to $1200 \mathrm{ergs} / \mathrm{mm}^{2}$, resulting in the appearance of five distinct colony morphologies, from fuzzy, creamy, compacts, pleated, plane, delimited boards, adhered to the middle. The micromorphology revealed changes such as: thick, short or completely pleomorphic hyphae, and spherical, oval, pyriform, rare or contained conidia [7]. Hyaline conidia in pigmented isolates, usually located in the tip of the condiophores, tend to become oval, elliptical or pyriforms, whereas pigmented conidia, located along the hyphae, were more spherical or oval in shape [3].

The ultrastructural presence of electrodense granules on the surface of the cell wall in wild type conidia and their absence in mutant albino conidia demonstrate the mutagenic effect of the UV radiation dose used in this study, which confirms the ability to generate albino conidia [5].

The survival and viability of pigmented conidia of S. schenckii exposed to $300 \mathrm{erg} / \mathrm{mm}^{2}$ of UV radiation were $66 \%$ and $96 \%$, respectively. Similar studies have described a high variation in survival and viability, with values of 38\%, 64\% [7] and close to 90\% [5]. However, the viability seen in this study was higher and less variable than those previous reports; nevertheless, when a radiation dose of 300 to 1200 ergs was employed, the viability ranged from 15 to $93 \%$ [7]. Consequently, the survival and viability of conidia varies according to the UV radiation dose, but also varies among the isolates when similar doses of radiation are used [7].

Mutant albino conidia converted to the yeast form, corroborating previous findings of others [7]. In addition, the photoreactivation of albino colonies exposed to 300 ergs of UV radiation is dictated by intrinsic fungal enzymatic pathways following activation by visible light [8].

\section{CONCLUSIONS}

Conidia from the studied isolates produced DHN melanin. The exposure of pigmented conidia to $300 \mathrm{ergs} / \mathrm{mm}^{2}$ of UV radiation was lethal, but, for the conidia that survived, no effects on cell viability and conversion to the pigmented or yeast forms were observed. The albino colonies produced by UV radiation (300 ergs $/ \mathrm{mm}^{2}$ ) photoreactivated upon exposure to visible light. 
Acknowledgments. The authors thank CNPq, CAPES and FAPERGS for the funding of this study and for granting scholarships to students engaged in this research. The authors also express thanks to Prof. Ary Santos (Institute of Chemistry and Physics -UFPel) and Prof. Severo Barros (Faculdade de Veterinária UFPel) for the invaluable assistance with the studies involving UV radiation and the ultrastructural analysis by transmission electron microscopy, respectively.
Moreover, we acknowledge Dow Agrosciences for donating the tricyclazole for the experiments.

\section{Sources and Manufacturers}

${ }^{1}$ Triciclazol - Dow Agrosciences Ltda. Rua Alexandre Dumas, São Paulo - SP, Brazil.

${ }^{2}$ Potato dextrose $\operatorname{agar}^{\circledR}$ (PDA) - Merck KGaA, Frankfurter Str. 250, D-64293, Darmstadt, Germany. ${ }^{3}$ Brain-heart broth $^{\circledR}$ - Merck KGaA, Frankfurter Str. 250, D-64293, Darmstadt, Germany.

\section{REFERENCES}

1 Bell A. A. \& Wheeler M.H. 1986. Biosynthesis and functions of fungal melanins. Annual Review of Phytopathology. 24:411-451.

2 Butler M.J. \& Day A. W. 1998. Fungal melanins: a review. Canadian Journal of Microbiology. 35: 728-734.

3 Lacaz C.S., Porto E., Heins-Vaccari E.M. \& Melo N.T. 1998. Identificação dos fungos. In: Fungos, actinomicetos e algas de interesse médico. São Paulo: Sarvier/Fapesp, pp.326-330.

4 Morris-Jones R., Youngchim S., Gomez B.l., Aisen P., Hay R.J., Nosanchuk J.D., Casadevall A. \& Hamilton A J. 2003. Synthesis of melanin-like pigments by Sporothrix schenckii in vitro and during mammalian infection. Infection and Immunity. 71: 4026-4033.

5 Romero-Martinez R., Wheeler M., Guerrero-Plata A., Rico G. \& Torres-Guerrero H. 2000. Biosynthesis and functions of melanin in Sporothrix schenckii. Infection and immunity. 68: 3697-3703.

6 Tokousbalides M.C. \& Sisler H.D. 1979. Sites of inhibition by triciclazole in the melanin biosynthetic pathway of Verticillium dahliae. Pesticide biochemistry and physiology.11: 64-73.

7 Torres-Guerreiro H. \& Arenas-Lopez G. 1998. UV irradiation induced high frequency of colonial variants with altered morphology in Sporothrix schenckii. Infection and immunity. 68: 3697-3703.

8 Tortora G.J., Funke B.R. \& Case C.F. 1997. Microbial Genetics. In: Microbiology an introduction. 6th edn. California: Adilson Weslwy Longman Inc., pp.207-241. 